\title{
Tsunami threat versus development activities along the coast of Pakistan: a geographic assessment
}

\author{
Mahar G.A., Ahmed R., Iqbal M.J. and Azam M. \\ Department of Geography, Federal Urdu University of Arts, Sciences and Technology, Gulshan Campus Karachi \\ Received: 30/08/2018, Accepted: 28/12/2018, Available online: 07/01/2019 \\ *to whom all correspondence should be addressed: e-mail: \\ https://doi.org/10.30955/gnj.002878
}

\begin{abstract}
Pakistan is located at the earthquake prone zone. The west coast of the country is in a zone of serious seismic hazard because of possessing a subduction zone. This area has been victimized by several severe earthquakes and tsunamis in the past. Bathymetric and earthquake interpolated maps have been prepared for risk assessment. Growing population, development and planning along the coast of Makran, especially at Gwadar, could be a serious risk in future without seismic hazard assessment. Considering the safety measures against the probable tsunami, special attention must be paid in the prospect of planning and development along the coast. This article is an attempt to assess the magnitude of the risk on behalf of onshore and offshore morphologic configuration with their tectonic setup.
\end{abstract}

Keywords: Tsunami, earthquake, coast, subduction zone, development activities.

\section{Introduction}

Coastal areas possess great potential for economic opportunities of trade, commerce, fishing and recreation (World Bank, 2017). The coastal areas on one side are important for the economy of the country and on the other side are vulnerable to natural disasters like coastal floods, cyclones and tsunamis (Rahman, 2013). Their strategic and geopolitics importance to the country is also considerable (Ghani, 2013). Pakistan is one of many countries of the world blessed with the coastal region. Its coastal belt runs from Sir Creek in the east to Dasht delta in the west, broadly bounded by Sindh coast (east) and Makran coast (west).

The western coastal belt has been victimized by many earthquakes and tsunami in the times past (Penney, 2017). The large earthquakes along the Makran Subduction Zone (MSZ) have generated destructive tsunamis in the past (Berninghausen, 1966). The largest recorded earthquake with the magnitude of 8.1, generated tsunami along the Makran coast on November 28,1945 , resulted in a great loss of life and destruction at the coast of Pakistan, Iran, India and Oman (Qureshi, 2006; PMD, 2005; Mokhtari and Farahbod, 2005;
Pararas-Carayannis, 2006). After passing a large period of 70 years, the probability of occurrence of a major earthquake and tsunami should not be ignored. The urbanization and coastal development projects are in progress, especially near Gwadar. This article is an attempt to evaluate the probability of tsunami occurrences alongshore and the development activities on the western coast of Pakistan.

Alignment of the subduction zone of Makran is just parallel to the coast of Makran. Many scientists and researchers are of opinions that this region is located at seismic hazards risk zone. Heidarzadeh et al. (2008) studied by numerical modeling of historical tsunami in this region and evaluated 7 major earthquakes since $326 \mathrm{BC}$ to 1945 AD. This historical record produces the Tsunami generation model in this region.

Heidarzadeh et al. (2009) simulated the near-field flood of two large tsunamis in Makran in the development of flood maps for the northwestern India. These two tsunami scenarios produced a run up height of $12-18 \mathrm{~m}$ and 24-30 m, respectively. William D. Page in 1979 also estimated that uplift of 1 to 3 meters in height occurs at Pasni and Ormara resulting from the earthquake of 1945 (M 8.3). On 24 September 2013, an earthquake of 7.7 magnitudes occurred in this region (Iqbal et al., 2017). After this shock, a small ridge rose out of water from $2 \mathrm{~km}$ of Gwadar coast. This is now known as Zalzala koh, which may be a submerged volcano before rising to the surface. This is an integrated study in which seismic, tectonic, bathymetric, morphologic and geographic setup are configured to evaluate the tsunami hazards especially along the Makran coast and its precautionary measures are discussed. Each section is separately discussed and associated with others to find out the sensitivity of the situation.

\section{Materials and methods}

Main objective of the study is to expose and interpret geographic, geomorphic, tectonic and seismic conditions and their association with each other. Many maps of the study area have been prepared to identify the sensitivity of the issue. A detailed account of these maps is given below. 


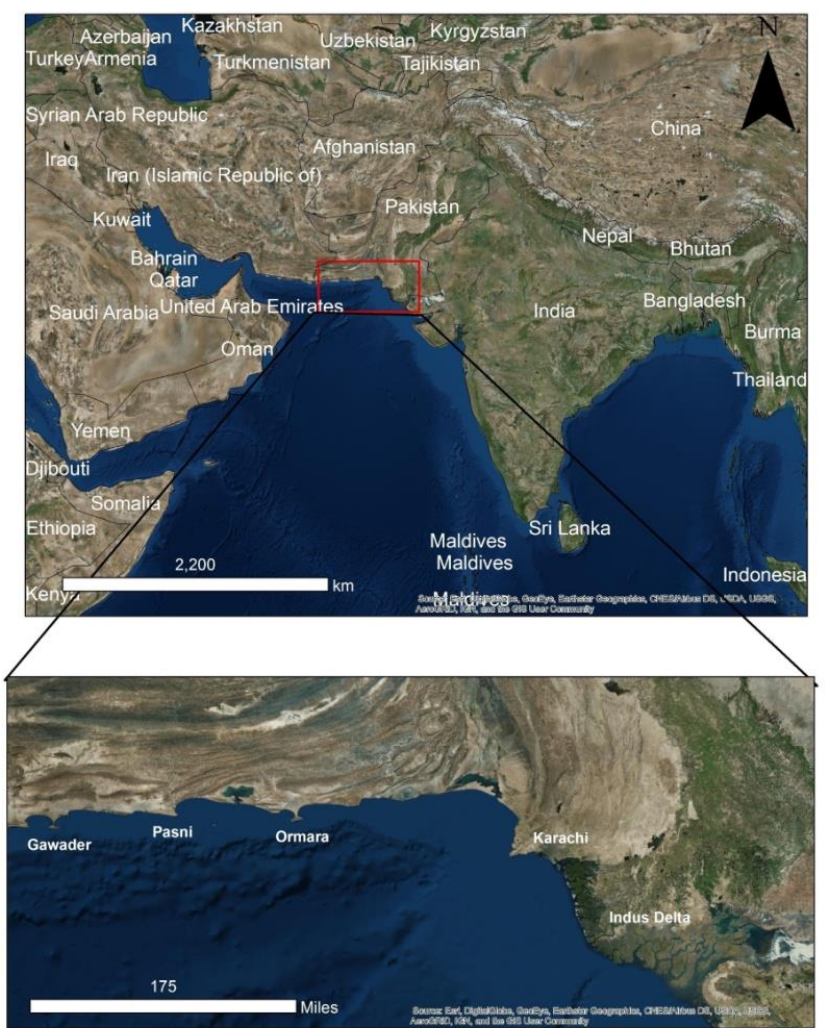

Figure 1. Satellite view shows the location of the coast of Pakistan

\subsection{Bathymetric map}

Bathymetric map has been developed with the help of digital bathymetry data. The 30-seconds satellite bathymetry data have been downloaded in .gz format from official site of National Oceanic and Atmospheric Administration (NOAA). Bathymetry data was collected from satellite data with several other sources and compiled by National Geophysical Data Center (NGDC) of NOAA in 1998 (GLOBE, 1999). This data was acquired in compressed text format from NGDC and have been initially uncompressed and converted into the comma delimited text file and saved as .csv file. This file has been converted into point data plotted in specified location using add event tool of Arc map. The text file (.csv) is now converted into spatial data by this method in Arc Map. Kriging interpolation method was applied by using point data plotted including Z-value because all the data has been compiled in grid format. This way a bathymetry map of the whole coast of Pakistan was developed.

Slope profiles graphs of the continental shelf along the specific location where settlements are found have also been developed. These profile graphs have been made on the bathymetry map using the spatial analyst tools. The bathymetry is 3-Dimension map where depth values along the coordinates are given. An interpolated line was drawn on the specific locations of bathymetry to get the slope profile graph.

\subsection{Aspect map}

Aspect map was made with the help of the Z-value of bathymetry map. The Aspect identifies the down slope direction of the maximum rate of change in value from each cell to its neighbors (ESRI, 2014). 3D analyst tool in Arc map was used to make the Aspect map from bathymetry map. Eight directions from 0-360 degrees are categorized to develop the Aspect map from this tool. Slopes with directions in different colors are shown in the legends. This map is helpful to show that which aspect of topography found in the map is dominant.

\subsection{Seismic map}

Seismic zoning map was also developed using the earthquake data. Archive historical earthquake data from 1905 to 2013 have been collected from USGS (2013) and compiled in excel. Magnitude of the earthquakes with the location of the epicenter in the form latitude and longitude is included in the data. This data has been converted into point data plotted in the map, using the Arc map program. Now, the attribute data of excel file is converted into spatial data by this method. Inverse Distance weight (IDW) interpolation method was used to developed seismic map. This map was classified into seven classes with the interval of 0.5 magnitude to evaluate the major and minor places of earthquake. Location of the epicenter in the form of the point data has also been displayed with the map for analysis.

\subsection{Other maps}

Fault maps have been developed using the cartographic techniques in Arc map program where as location and orientation of the faults, direction and propagation of waves were manually digitized.

An exposure map has also been developed. Three buffer zone of 1000 meters interval was prepared on the map. Four settlements in exposure map were selected and enlarged on separate clips so that exposed area with three buffers could be analyzed.

\section{Geographical setup}

Pakistan has a total $1,050 \mathrm{~km}$ coastal strip that lies within the subtropical region and divides Sindh (350 km) and Makran (700 km) coast by Cape Mounze (Figure 1). Eastern side of the coast comprises of creeks of Indus delta that starts from Sir Creek in the east to Gizri creek in the west. The coastal area of Karachi starts from Korangi creek, giving a curve-move to Cape Mounze in the west. Beyond the Cape Mounze, the Makran coast begins. In eastern coast of Makran, a lagoonal structure is found known as Miani Horr. The physiographic location of this structure supports that this area is appropriate for the development of harbor. About $200 \mathrm{~km}$ from Son-miani, Ormara with Tambola structure is found. Pasni is another settlement that is between Ormara and coast. city is one of the major settlements on the Makran coast. A major regional port is going to be established in this city that would connect the Indian Ocean with China and central Asian countries in future. It is expected 
that geographical position of western coast of Pakistan will be regionally centralized in future.

\section{Bathymetric setup}

The eastern coast is highly indented with number of creeks having a wider continental shelf. In contrast the Makran coast has a narrower continental shelf with a smooth coastal margin. Makran ranges cover the vast area which is about $400 \mathrm{~km}$ long and $250 \mathrm{~km}$ wide (Kazmi and Jan, 1997). The Makran region comprises a monotonous series of parallel ridges and valleys (Kazmi and Jan, 1997). The presence of raised beaches and marine terraces along the Makran coast indicates episodic uplift of the continental margin resulting from large-magnitude earthquakes. Karachi coast is east-west oriented which starts from Cape Mounze to Korangi creek, from where Indus Delta starts comprising of the seventeen major and many minor creeks. It ends at the Sir creek, an international boundary between Pakistan and India (Mahar, 2006; Mahar, 2010).

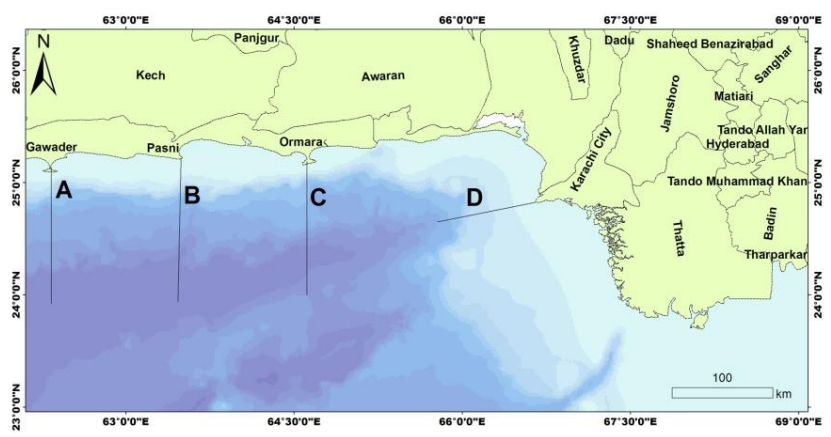

Depth value in meter
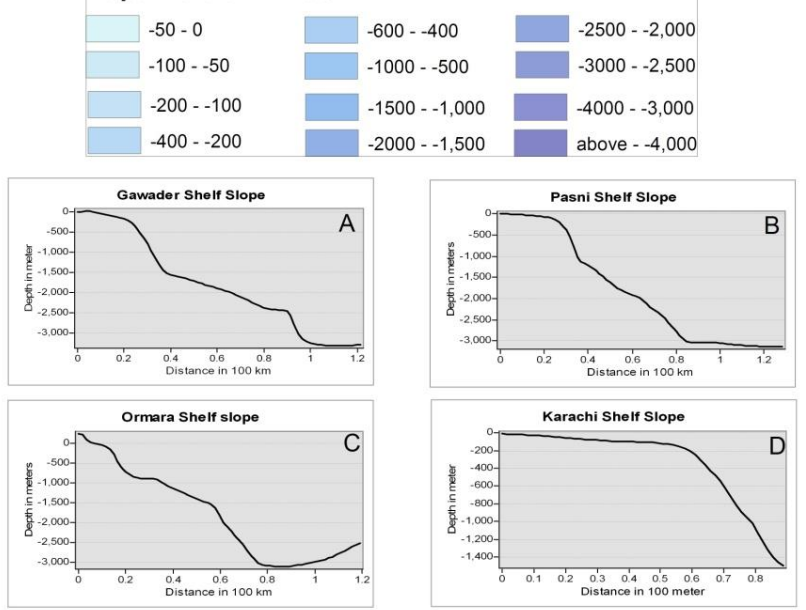

Figure 2. Bathymetric map of Arabian Sea along the coast of Pakistan and specific locations of the graph of the shelf slope where settlements are found (Source: Authors)

Continental shelf along the coast of Pakistan which is fairly rich in marine biodiversity provides the potential environment in the Exclusive Economic Zone (EEZ). The shelf is about $130 \mathrm{~km}$ wide off the Indus Delta but along the Makran coast, it narrows down to 20 to $50 \mathrm{~km}$ (Figure 2). The slope is average $150 \mathrm{~km}$ wide off the delta and 20 to $40 \mathrm{~km}$ wide in the Makran region (Figure 2). The sea floor is characterized by a number of physiographic features; those are significant from morpho-tectonic stand point (Kazmi and Jan, 1997).

Bathymetry and four Slopes' profiles of the continental shelf explain very certainly and categorically that shelf of western coast (Makran coast) is very steep and eastern shelf is comparatively more gentle (Figure 2). Estimated Shelf slope of the coast is $3 \%$ from coast to $100 \mathrm{~km}$ off shore. Pasni and Ormara show same slope value that is $3.75 \%$. Karachi shows comparatively different slope. Shelf slope from the coast of Karachi to $60 \mathrm{~km}$ off shore is $0.33 \%$ that is very gentle while between 60 and $100 \mathrm{~km}$ shelf slope is $3.25 \%$. Bathymetric map and these profiles show that eastern coast due to the deposited sediments from River Indus is very gentle while western coast (Makran) has steep shelf slope. In some of the places of off shore Makran coast, 50 meter depth was found just 10 to 20 meter away from the coast.

Topography developed on the Figure 3 shows the slope direction. Sky blue color on the shelf slope of the Makran coast exhibits that shelf slope directed towards the south is dominant. Few west oriented anticlines are found but overall slope is inclined towards south. A north oriented belt is also found on the map near the subduction zone. Eastern coast, from Karachi towards Indus delta is inclined towards southwest and west. Slope and its direction on the Aspect map show that shelf slope of Makran coast is inclined towards south with few anticline ridges till $100 \mathrm{~km}$.

The Murray Ridge is located southwest of Karachi in the Arabian Sea where normal faults exist on this ridge. A subduction zone lies around $100 \mathrm{~km}$ away from the Makran coast, which is a threat to the coastal region of Balochistan because it has the potential to generate tsunamis towards the coastal area of Pakistan (Figure 3). Distance of subduction zone and shelf slope near the Makran coast support the hypothesis that probable tsunami from this subduction zone can hit the coast with larger scale.

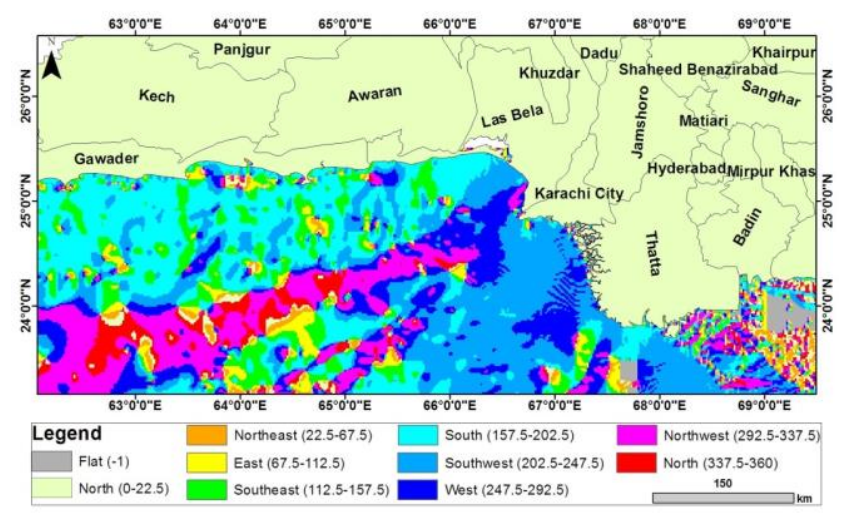

Figure 3. Aspect map of the continental shelf of Pakistan Coast where slope with direction is shown

\section{Tectonic setup}

The location of Pakistan with the reference to regional tectonic setting is very crucial. Three plates Eurasian and Indian and Arabian plate configure the country on the 
earthquake prone zone. Geologic characteristics and tectonic features divide Pakistan into six major units (Loya, 2000). One important zone lies at the southern margin of the Afghan craton (Figure 4), associated with the subduction of the Arabian oceanic plate under the southern margin of the Afghan craton (Gaina et al., 2015).

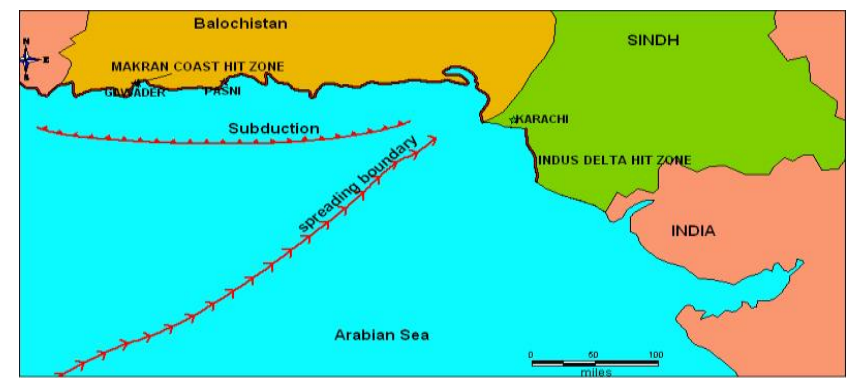

Figure 4. Subduction zone and spreading plate boundary at the continental shelf of Pakistan

A subduction between the Arabian and Indian plate along the off shore of Makran coast is also a very important tectonic structure. This subduction zone has developed a belt of accretionary flysch sediment near the coast. Murray ridge is another seismic structure of particular importance located in the continuity of Cape Monze in the offshore of the Arabian Sea (Figure 4). Murray ridge is thought to be an active rift zone shifting southwestnortheast, extending toward Sonmiani (Loya, 2000).

\section{Off shore seismic activities}

Off shore seismic conditions under the present development activities along the western coast of Pakistan are significantly important. Its negligence could cause a big loss to the country. The rest of the coastal area of the country is not a risk free zone. Many disastrous earthquakes along this region have occurred in the past. Seismic data suggests that we have had frequent earthquakes of moderate magnitude along the coast in the last century. Even Makran subduction zone triggered the second deadliest tsunami in the Indian Ocean, among those the known tsunami hazards in this region has not been analyzed in detail (Heidarzadeh et al., 2009). The archive data of earthquake (USGS, 2014) has been compiled in ArcMap - GIS software. Seismic zoning of the off shore coast is developed on the basis of the location of the epicenter (Figure 4). Inverse distance weight interpolation method is applied against the past occurred earthquake on the offshore coast of Pakistan. The interpolated results are divided into five zones based on the magnitude of the earthquakes (Table 1).

Classified map of the seismic zoning depicts a clear picture of the offshore region of Pakistan (Figure 5). It divides the whole area into two regions of seismic importance; the coastal region of Makran and the coastal region of Sindh. This map, based on chronological data represent that seismic activities are different in both regions. These two regions also have entirely different geographic, geologic and geomorphic features. The coast of the Sindh is supposed to be more secured as compared to the coast of Makran.

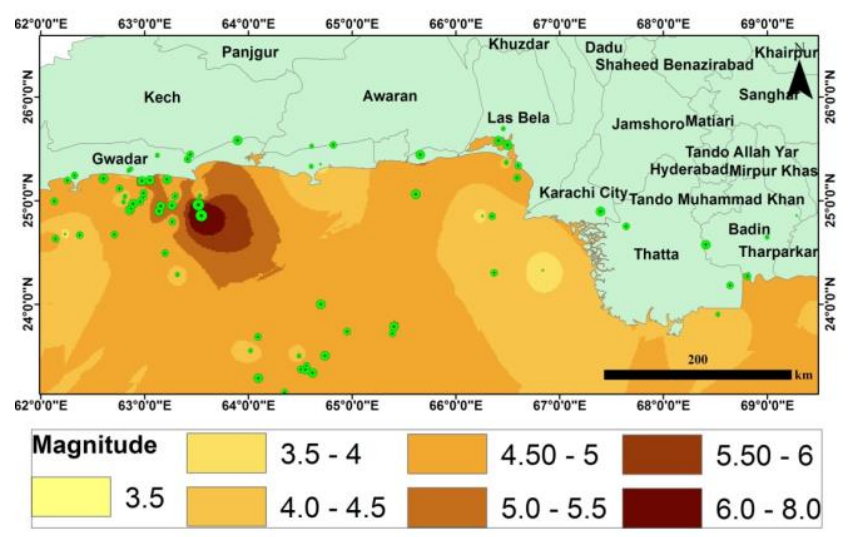

Figure 5. Map showing the seismic zoning based on magnitude and location of epicenters of historically occurred earthquake of the offshore coast of Pakistan. Source: USGS, 2014

The whole part of coastal Balochistan, particularly the western area comes under the high risk zone. Figure 5 indicates that many disastrous events have occurred on the western part of the Makran coast. Occurrences of these disastrous incidents on the offshore side have generated Tsunami in the past. Ormara, Gwadar and Jiwani are the important settlements of the province and have been affected in the past. Locations of large number of epicenters are found near Gwadar and Jiwani. Growing population in these settlements and urbanization in the Gwadar port without the assessment of the seismic hazards could be dangerous.

\section{Tsunami waves towards the coast}

Subduction zone located along the Makran coast in Arabian Sea is about $100 \mathrm{~km}$ from the coast. This zone and the associated thrust faults are east-west oriented, which is aligned with the coast of Karachi towards east. A thrust in the Arabian Sea could generate tsunami that will directly strike northward to the Makran coast and southward to Indian Ocean. If a thrust is developed by earth quake, about $100 \mathrm{~km}$ distance of subduction zone from Makran coast generating tsunami will take only few minutes to strike the Makran coast. This model based speculation is a potential threat to the Makran coast.

The direction of tsunami from the same thrust towards Karachi could not have much larger damage as compared to Makran coast because of the geographic location of the Karachi city. Coastline of the Karachi city is east-west oriented and it is separated from north-south Cape Monze promontory which provides a barrier to the city and moreover, location and direction of the fault in the Arabian Sea, making it comparatively secure. Associated thrust faults are east-west oriented in direction, which is located to the south-west of the city. It's alignment with Karachi can propagate weak tsunami and a probable generated Tsunami along the Makran coast can strike Ormara, Pasni, Jiwani and Gwadar coast at high angle but the same may strike Karachi at low angle (Figure 6) 
because these waves will be weaker in the eastern and western direction and its direction will be parallel to the Karachi coast so probably, degree of destruction in Karachi city is very low provisionally that the tsunami originating from this subduction zone.

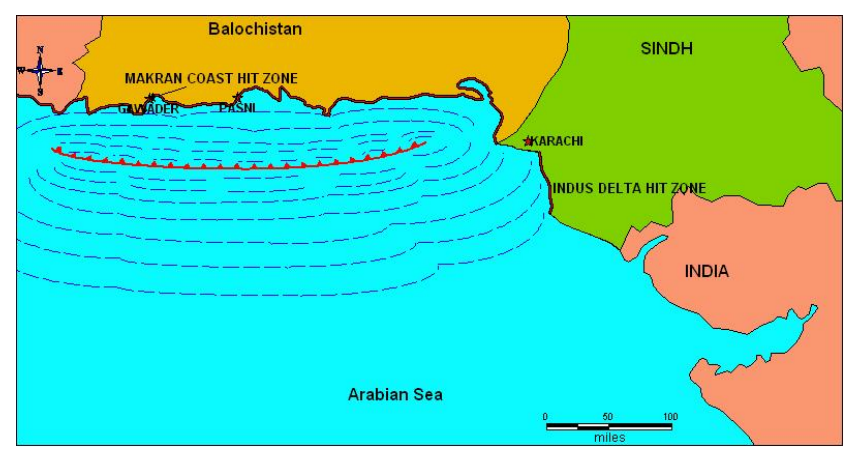

Figure 6. Subduction zone along Makran coast showing the direction of propagation of waves

Three major earthquakes (1945, 1947 and 2013), generated Tsunami, have occurred in this region in last 80 years (Iqbal J. et al., 2017; Kazmi and Jan, 1997). History shows the earth quakes from this subduction zone along the coast, always stroke the Makran coast but because of low population, less amount of loses were recorded but in future population and development activities are rapidly increasing so in case of any probable major shock, loses could not be comparable with the past.

Murray ridge is one of the prominent features in the continental shelf of the Arabian Sea. It is south-west to north-east oriented and it is located in the south-west of Karachi city. Spreading plate boundary on the Murray ridge can cause to produce a fault over the ridge. This probable fault could generate tsunami but tsunami generated from spreading plate boundary is comparatively lesser energetic then the tsunami generated from subduction zone because these waves cannot hit the Makran coast at $90^{\circ}$. It could cause small damage of property and loss of life. Again the direction and location of spreading boundary towards Karachi is itself a barrier, and any thrust generating tsunami propagates waves north-west and south-east direction that is shown in Figure 7.

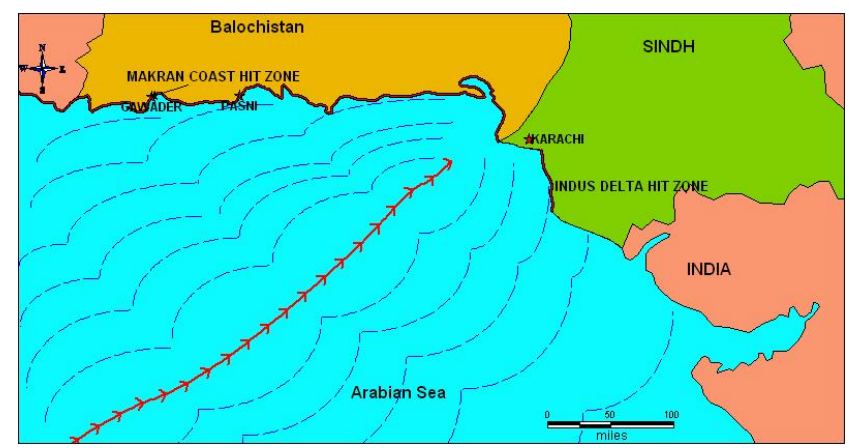

Figure 7. Spreading boundary along the Murray ridge shows the direction of propagation of waves

\section{Coastal settlements and development activities}

Two important ports, Karachi and Gwader are located along the coast of Pakistan. Karachi, the biggest city of the country, has a population of about 20 million. It is a commercial city and plays an important role in the economic development of the country. The territory of Gwadar was given the status of a separate district in 1977 and happens to be among the largest coastal districts in the country, with a population of 185,498 and 263,514 as recorded in 1998 and 2017 census respectively (Pakistan Bureau of Statistics, 2017). Two more settlements are found where losses could be quantified on the occurrence of incident.

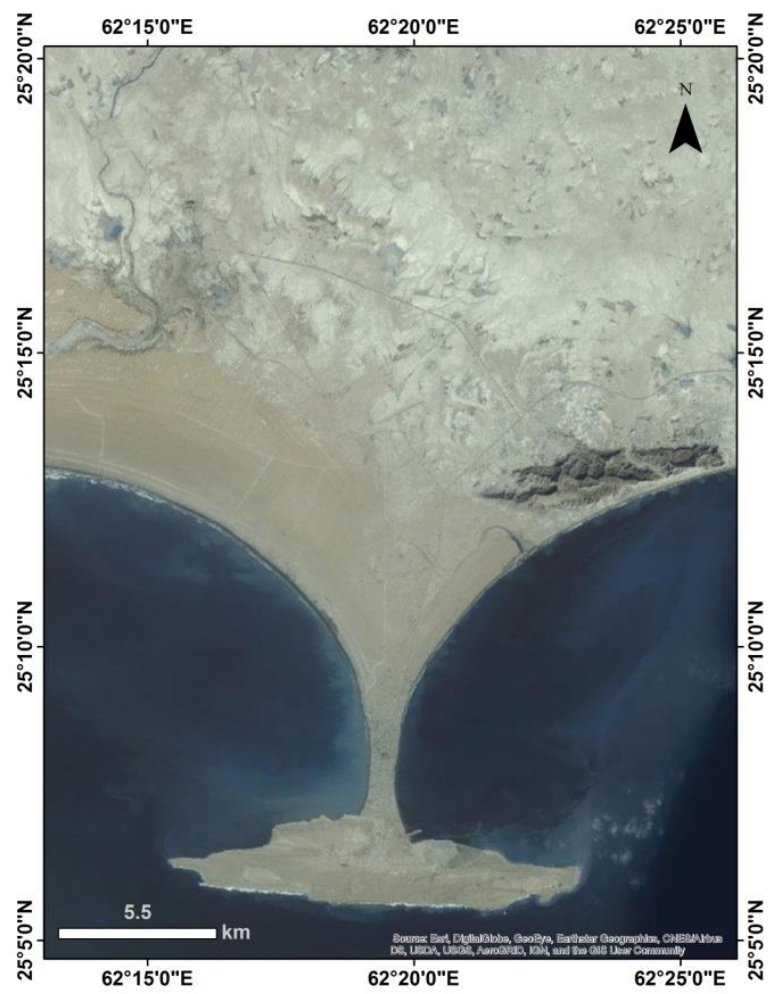

Figure 8. Figure shows the Tombolo structure of Gawadar city

Gwadar port has started working since 2006 despite the political and geopolitical issues. After the agreement between China and Pakistan on China Pakistan Economic Corridor (CPEC), development activities have been boosted up in the city of Gwadar. The bottle neck of tombolo of the Gwadar city has already been covered with settlements (Figure 8). Layout maps of the surrounding area have been developed for urban planning and management. Many development activities have been started. Eastern coast from Tombolo towards north has been allotted to the Chinese for the development of the port and other settlements. Tombolo is a hilly area, where a five star hotel was constructed in 2006 and total coastal area was allotted to local people and people across the country. Western area has been planned for city development. Gwadar Development Authority (GDA) was established for planning and management in 2003. Presently the 
city is about $20 \mathrm{~km}$ from the coast of Gwadar to N10 highway which is also known as RCD road. Western area is expanded up to $40 \mathrm{~km}$ west along the marine drive road.
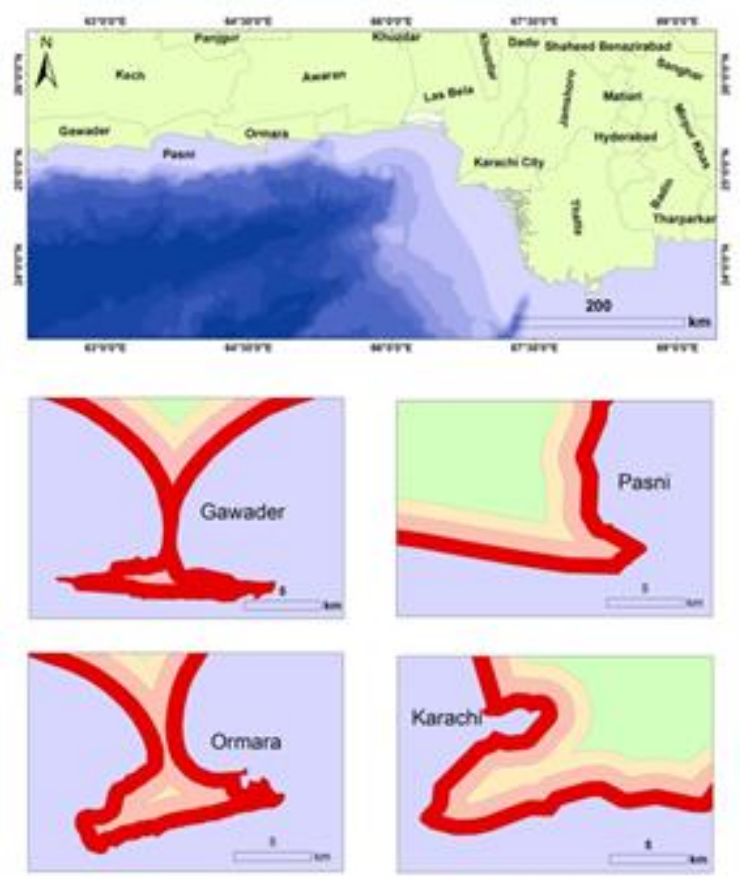

Risk zones (in meters)

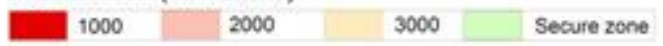

Figure 9. Exposure map shows three buffer zones with 1000 meter interval. Four main settlements were selected to shows vulnerability of the area

Three buffer zones demarkated on the coast at the interval of 1000 meters estimate how much area could be invaded by the waves on the occurrence of Tsunami (Figure 9). First buffer of 1000 meter is most dangerous while second is comparatively lesser and last one is least danger. Beyond the 3000 meter area could be secure because on average $3000 \mathrm{~m}$, foothills of the Makran range are found but in some remote places along the coast, foot hills of Makran range were found just on the coast. Four settlements have been exposed on the map to show that how much area should be made ready as most dangerous and less dangerous. In nutshell Tombolo structure of Gwader will be most vulnerable. It is a hilly area but it could not stop the invaded waves as the distance of generated Tsunami would be $100 \mathrm{~km}$. This city is expanding towards east, west and north. Safety measures must be followed against tsunami in planning and development. Ormara and Pasni are small settlements but losses could occur because beyond a periphery of 1000 meters area is not considered to be out of danger. Exposed area of the Karachi is the Cap mounze promontory that is a hilly area and it is not that much populated. Gentle slope, near off shore and ridge on the land will dissipate the strength of the waves but safety measure must be taken as the whole city is densely populated.

\section{Discussion and recommandations}

Spatial analyses of the seismic conditions at the coast of Pakistan suggest that this area is at high risk zone while the western coastal belt of the country is located on the category of highest risk zone. In case of occurrence of such a disastrous event, it is essential for the people living in Gwadar, Ormara and Pasni to secure their lives. Safety measures are very necessary for future disastrous events, so that the loss of life and property damaged can be minimized and people can be saved.

Considering the safety measures and life saving of the people of the coastal area, it is imperative to pay especial concentration to evaluate the overall scenario of seismicity in detail for the micro-seismic zoning of the whole area of coastal belt and especially the Makran coast. Detail study of geology and geomorphology help to plan the urbanization of small town near the coast in future.

Urbanization of the coastal cities must be carefully planned. Seismic, geologic, geomorphic and geographic study should be under consideration in the development programs and urbanization of towns like Gwadar. The Settlement of Gwadar at the tombolo is very dangerous. Industry or city must be planned at the site at least $5 \mathrm{~km}$ away from the coast. Micro-seismic study and geologic background of any place help to suggest the construction of building in accordance to particular rector scale.

Use of recording gauges for the warning of probable tsunami and for the recording of run-ups at the time of waves attack is very essential because in this way people could be informed about the tsunami and could be saved from large number of loss of life and damage of property. Third world still lacks to secure their coast from the probable tsunami because most of the countries of the third world have not installed the recording gauges to measure the run-up of waves. Warning system is very essential even to those places where there is no settlement and where location of settlements is secure from probable tsunamis because it not only gives us security but it also gives us a continuous data for regional based future planning.

Embankments should be constructed along some active spots of the coast especially around the settlements like Gwadar, Pasni, Ormara and Sonmiani so that the probable waves could divert their direction. In this way the impact of the tsunami can be minimized and thus its dissipated strength will be less destructive and could prevent from further losses.

Karachi being a commercial and the largest city of Pakistan is in dire need of warning systems for long term planning, along the coastal zone of Karachi, which is very essential despite the fact that it is geographically and geomorphically secured. Smaller shocks and minor thrust of tsunami near the coast of Karachi could create damages 
on a large scale because of the unplanned settlement of a large population near the coast.

People living along the coastal area should be trained and well informed about the tsunami, so that they could recognize the siren of tsunami warning and they should know how to approach and climb the elevated places like building or hilly area. Clinical health safety measures near the coastal area should be established and all requirements, necessary to secure the lives of people should be fulfilled.

Analytical overview of the coastal belt depicts a preview of the natural disasters and draws attention of the policy makers regarding the security and safety of the coast.

\section{Summary \& conclusion}

Coastal zone of Pakistan especially Makran coast was studied from many dimensions.

i. An interpolated bathymetry map was generated with $50 \mathrm{~m}$ to $500 \mathrm{~m}$ contour interval.

ii. Shelf profile of specific locations was generated from bathymetry map.

iii. Aspect map with the help of Bathymetry map was also generated.

iv. Interpolated seismic map of past 108 years (1905-2013) was generated.

v. Map of faults on study area were also prepared with location and orientation.

vi. Tsunami propagation map was also prepared along the faults to show direction and propagation of waves.

vii. A vulnerability map with three ordinal risk zones of 1000 meters was prepared with exposure of four settlements.

Analysis of the integrated study of coast and shelf of Pakistan using bathymetry data, seismic record, and tectonic situation, wave propagation model and coastal vulnerability map let to understand the level of vulnerability and led to take precautionary measures because known ignorance of probable natural hazards could cause a serious disaster especially along the Makran coast.

It is concluded that the coastal belt located near the subduction of Makran is the serious seismic zone of danger. While these tectonic structures against location of the Karachi coast, somehow secure the city from such disastrous events. Similarly, Indus delta due to its location and alignment is supposed to be secured from western shocks but seismic records show that it is insecure from its eastern threat of shocks.

Growing population and settlements indicate that development activities in the future will increase along the Makran coast. Similarly, the density of population will also increase at some places along the coast. The overall scenario let to conclude that any tsunami generated along the coastal belt of Makran could produce the disastrous event and claim losses.

\section{References}

Berninghausen W.H. (1966), Tsunamis and Seismic Seiches reported from regions adjacent to the Indian Ocean, BSSA, 56(1).

D.C.R. (2017), District Census Report, In: Pakistan Bureau of Statistics, Government of Pakistan, Islamabad, Pakistan.

ESRI. (2014), Environmental System Research Institute, Redland, California, USA. Web site: www.esri.com.

Gaina C., Douwe J.J. Van Hinsbergen and Spakman W. (2015), Tectonic interactions between India and Arabia since the Jurassic reconstructed from marine geophysics, Ophiolite Geology, and Seismic Tomography, Tectonics, 34, 875-906. doi:10.1002/2014TC003780.

Ghani O.A., Agha M.A., Gul A. and Shah A. (2013), Regional Geostrategic Challenges and Opportunities for ChinaPakistan Cooperation. China Pakistan Joint Think tank, National University of Science and Techmology, Islamabad. p. 30.

GLOBE Task Team and others (Hastings D.A., Dunbar P.K., Elphingstone G.M., Bootz M., Murakami H., Maruyama H., Masaharu H., Holland P., Payne J., Bryant N.A., Logan T.L., Muller J.-P., Schreier G., and MacDonald J.S.), eds. (1999), The Global Land One-kilometer Base Elevation (GLOBE) DigitalElevation Model, Version 1.0. National Oceanic and Atmospheric Administration, National Geophysical Data Center, 325 Broadway, Boulder, Colorado 80303, U.S.A. Digital data base on the World Wide Web:http://www.ngdc.noaa.gov/mgg/topo/globe.html.

Heidarzadeh M., Pirooz M.D. and Zaker N.H. (2009), Modeling the near-field effects of the worst-case tsunami in the Makran subduction zone, Ocean Engineering, 36(5), 368-376.

Heidarzadeh M., Pirooz M.D., Zaker N.H., Yalcine A.C., Mokhtari M. and Esmaeily A. (2008), Historical tsunami in the Makran Subduction Zone off the southern coasts of Iran and Pakistan and results of numerical modeling, Ocean Engineering, 35(8-9), 774-786.

Iqbal J., Ishaq A.K.J., Raja I.A. (2017), Balochistan Earthquake in 2013: Emergence of new Island in the Arabian Sea, SDRP Journal of Earth science and Environmental Studsies, 2(1).

Kazmi A.H. and Jan M.Q. (1997), Geology and Tectonic of Pakistan. Graphics Publishers, 5C, 6/10 Naziamabad, Karachi, Pakistan. ISBN: 967-8375-00-7, p 39-40, 184-185, 414-415.

Loya A.R., Zaigham N.A. and Dawood M.M. (2000), Seismic Zoning of Karachi and Recommendations for Seismic Design of Building, Published by Association of Consulting Engineers Pakistan (ACEP) and Karachi Building Control Authority (KBCA).

Mahar G.A. (2010), Geomorphic Degradation of Indus Delta and Its Demographic Impact. Ph.D. thesis, Department of Geography, University of Karachi, Karachi.

Mahar G.A. and Nayyer Z.A. (2006), Tsunami Generation and propagation along the Coastal Zone of Makran and Karachi, Proc. Advances in Space Technology, Islamabad, Pakistan, Publisher IEEE, DOI: 10.1109/ICAST.2006.313804

Mokhtari M. and Farahbod A.M. (2005), Tsunami Occurrence in the Makran Region, Tsunami Seminar, Tehran, 26 February 2005. 
Pararas-Carayannis G. (2006), Alexander the Great - Impact of the 325 B.C. Tsunami in the North Arabian Sea Upon his Fleet, http://drgeorgepc.com/Tsunami325BCIndiaAlexander. html

P.B.S. (2017), Pakistan Bureau of Statistics Statistic House, 21Mauve Area, G-9/1, Islamabad, Pakistan. Website: http://www.pbs.gov.pk

P.M.D. (2017), Pakistan Meteorological Department, Headquarter Office Sector H-8/2 Islamabad. Website: http:// www.pmd.gov.pk.

Penney C. (2017), The South Coast of Iran and Pakistan Faces a Worrying Tsunami Risk, Independent Digital News and media, 2 Dery Street, London W8 5HF United Kingdom. Website: independent.co.uk.

Qureshi R.M. (2006), Vulnerability of Pakistan Coast to Tsunami. Possible Applications/Role of Nuclear Techniques. RCARO Workshop. Daejon, Korea.

Rahman R. and Salehin M. (2013), Flood Rsik and Reduction Approaches in Bankgladesh, In: Desaster Risk Reduction. Springer International Publishing AG, pp. 65-90.

USGS (2014). National Earthquake Information Center, World Data Center for Seismology, Denver, USA.

William D.P., Alt J.N., Cluff L.S. and Plafker F. (1979), Evidence for the recurrence of large-magnitude earthquakes along the Makran coast of Iran and Pakistan, Tectonophysics, 52(1-4), 533-547.

World Bank and United Nations Department of Economic and Social Affairs. (2017), The Potential of the Blue Economy: Increasing Long-term Benefits of the Sustainable Use of Marine Resources for Small Island Developing States and Coastal Least Developed Countries, World Bank, Washington DC. 